\title{
Efficiency of Individualised Resources in the Russian EFL Classroom
}

\author{
Olga Stognieva \\ National Research University Higher School of Economics \\ Correspondence concerning this article should be addressed to Olga Stognieva, National Research \\ University Higher School of Economics, Kirpichnaya, 33, Moscow, Russian Federation, 115187. \\ E-mail:2507794@mail.ru
}

\begin{abstract}
In order to plan lessons that include effective instructional strategies, it is critical for teachers to be aware of student aptitudes, personality variables, learning strategies, interests, aspirations, and talents. This paper presents a way for Russian teachers to improve their students' speaking abilities when learning foreign languages, called individualised resources, which are based on the concept of individualisation. Individualised resources are designed to help students to actively participate in the learning process, contribute to their productivity of learning and compensate for missing abilities when mastering foreign languages. In order to verify the effectiveness of this educational tool, qualitative and quantitative indicators were applied to a classroom-based study. Research findings illustrate how the approach enhanced the students' speaking abilities in terms of purposefulness, richness of speech content and logical progression of speech. The results presented in the article indicate that this type of training may be sufficient to shape speaking skills when teaching English.
\end{abstract}

Keywords: individualised resources, speaking skills, aptitudes, learning strategies, personality variables

Generally, individualised teaching is recognized to be an essential response to a number of pedagogical challenges and problems currently discussed with regard to the effectiveness of teaching (Diamond, 1975; Kuzovlev, 1997; Passov \& Kuzovleva, 2010; Bray \& McClaskey, 2015). From the late 1990s, individualisation has become a guiding principle for educational reform in Russia. The concept of modernising Russian education highlights the need to ensure differentiation and individualisation by using effective teaching methods, in particular for EFL learning.

Individualised learning is a method of teaching, in which content, instructional technology and the pace of learning are based upon the abilities and interests of each learner (Kuzovlev, 1997, p. 15). The principle of individualised learning has become an important aspect of teaching any school subject, and foreign languages in particular (Zimnaya, 1985, p. 8). Rogova, Rabinovich, and Sakharova (2004) maintain that foreign languages are more difficult than most subjects to learn because of the complex combination of skills and cognitive functions involved in the language learning process, which is why it requires an individual approach.
However, existing resource kits for teaching English, although they are well developed, suffer significant disadvantages. They are designed for the 'average' student and cannot take into account individual characteristics of each student learning a foreign language. Therefore, the question arises: Is it possible to develop supplementary educational tools, which will correspond to individual characteristics and the needs of the students? If teachers can develop and implement extra training tools, which take into account the individual and personal characteristics of students, such as the pace of progress, the abilities for foreign language acquisition, possible gaps in learning a foreign language, a personalised system of instruction, the way that teaching is structured and managed, the learning process will proceed more effectively. This paper aims to show that providing students with individualised learning resources, which are defined as a special type of training tool designed for the individualisation and personalisation of the learning process (Stognieva, 2003, p. 56), will result in their active participation in the learning process, and contribute to their productivity when learning a foreign language. 


\section{Materials and Methods}

\section{Students' Variables Relevant for Creating Individualised Teaching Resources}

Students collectively encompass a wide range of variables, including age, gender, intelligence, personality, learning style and previous learning experience, individual beliefs, attitudes, expectations, motivations and strategies for learning. This paper explores the notion of individualised resources, so this research focuses on the following three areas:

- Language aptitudes

- Learning strategies

- Personality variables

This section reviews the literature on student variables with respect to language learning and then examines the issues that arise from the literature particularly on creating individualized resources.

Language aptitude is one the most significant factors which determines individual's success in foreign language acquisition (Sparks \& Ganschow, 1991; Skehan, 1998; Sternberg \& Grigorenko, 2002). Carroll's (1981) language aptitude includes four components: phonemic coding ability (the capacity to identify distinct sounds and to code them for later retrieval), grammatical sensitivity (the ability to recognise the function of words in sentences), associative memory (the ability to learn associations between sounds and meanings and retain them) and inductive language learning ability (the ability to identify patterns in language use and to infer the rules that govern them).

O'Malley and Chamot (1993, p. 107) claim that while aptitude is generally assumed to be a fixed characteristic, it may be more adaptable to instruction than was originally anticipated. They find a close link between Carroll's four components of aptitude and language learning strategies, and propose that what has previously been defined as fixed aptitudes of learners may be redefined conceptually in terms of the strategies individuals use in learning situations. This has implications for pedagogic intervention, in terms of strategy training for language learners.

A learning strategy is a person's approach to learning and using information (O'Malley \& Chamot, 1990; Oxford, 1990; Biggs, 1992; Reid, 1995; Ehrman, 1996; Dörnyei, 2005). Students use learning strategies to help them understand information and solve problems. Students who do not know how or do not use good learning strategies often learn passively and ultimately fail at university. Learning strategy instruction focuses on making students more active learners by teaching them how to learn and how to use what they have learned to be successful. A strategy is useful when: (a) the strategy relates well to the L2 task, (b) the strategy fits the particular student's learning style, and (c) the student employs the strategy effectively and links it with other relevant strategies. Strategies that fulfil these conditions help students learn easier, faster and more enjoyable. Oxford (2001) points out that as with any type of instruction, foreign language learning strategy instruction is more effective when adjusted for learning styles.

There are four main personality characteristics affecting foreign language learning discussed here: motivation, self-esteem, anxiety and engagement.

Motivation is one of the most important variables in language learning (Gardner, 1985; Crookes \& Schmidt, 1991; Kormos \& Dörnyei, 2000; Ochsenfahrt, 2012). Not surprisingly teachers recognize the importance of motivation, both with regard to the motivation which students bring to the language classroom (extrinsic motivation) and the motivation that is generated inside the classroom through the choice of instructional activities (intrinsic motivation).

Many researchers claim that no successful learning activity can take place without some self- esteem and self-confidence (Coopersmith, 1967; Heyde, 1979; Brown, 1994; Ushioda, 2009). Brodkey and Shore (1976) revealed that self-esteem appears to be an important variable in second language acquisition, particularly in view of cross-cultural factors of second language learning.

Anxiety can be treated as a 'conceptually distinct variable' (Horwitz, Horwitz, \& Cope, 1986, p. 125) for high anxiety level reduces performance when learning a foreign language. Studies into anxiety in language learning have focused on 'a type of anxiety related specifically to language situations, termed 'language anxiety' (Gardner \& MacIntyre, 1993, p. 5), which includes self-perceptions, expectations, beliefs, feelings, and behaviours related to classroom language learning.

Bray and McClaskey (2015) consider that the learners want to be engaged with the content and they want to learn more about something they are interested in. This can be what inspires them to learn something.

The teacher should keep track of learners' aspirations, talents, interests, and passions. This will help define who they are as learners and how they learn best. If the teacher develops specific instructional and learning strategies, it can bring better performance in foreign languages.

What is important about the study of individual differences is that it allows the teacher to explore how instruction can be adapted to take account of the person who is most involved, the actual learner.

\section{The Interaction between Individual Differences and the Components of Individualised Resources}

In order to enable the most learners possible to learn as much as they can, the teacher should give them every advantage, including individualised resources that 
enable students to start out in a relatively comfortable and stress-free way. This means giving students the opportunity to learn in their preferred styles, to employ different kinds of supports (verbal or visual), different kinds of instruction (reminders, memos, checklists), motivating task objective presentations and material teaching aids which match their interests and other personal variables.

Figure 1 shows how each component of individualisation described above (i.e. aptitudes, learning strategies, and personality variables) is manifested in individualised resources. The structural components of individualised resources are: the task objective presentation that aims to motivate students for speech production; material teaching aids that create the informative and prompt basis for students' oral statements; instructions that demonstrate the sequence of task performances and aim to develop learning strategies; verbal and visual supports that may help students to produce statements, depending on individual aptitudes (Stognieva, 2003, p. 84). Each of these components to a varying degree should contribute to the overall goal of teaching oral communication in a foreign language.

The teacher's awareness of students' personality variables could help the teacher to state the task objective presentation and to choose the right teaching aids that could be informative and prompting. Informative teaching aids may consist of a fragment or several fragments of text based on one idea, newspaper or magazine articles, letters, diaries, tables containing specific data, pictures, photos, illustrations, drawings, sketches, etc. Prompting teaching aids may include slogans, aphorisms and sayings, diagrams, charts, statistical data, symbols, posters and cartoons.

The teacher's awareness of their students' aptitudes is reflected in supports - verbal and visual - that allow the teacher to design individualised resources for students with a varied degree of speaking ability. Different kinds of supports help the students to cope effectively with the tasks.

The teacher's awareness of students' learning strategies is introduced in instructions, reminders, memos and checklists that describe the steps of performing the task. Instructions and prompts are especially important when the task is given for the first time. On the one hand, the regular use of instructions and prompts facilitates the student's ability to follow instructions, and on the other hand, along with the supports they may help less able students to operate together with the class.

Before the teacher starts designing the individualised task, they should create a student's personal profile and then analyse the aptitudes, learning strategies and personality variables obtained for each student. In the next stage, the teacher should make instructional decisions based on learners' strengths, challenges, interests, and how they prefer to learn (in particular, what supports and instructions they may need, what material teaching aids will be the most effective in terms of calling communicative motivation).

There is an example of three different personal profiles of third year students who study at the Faculty of Business Informatics at the Higher School of Economics (Moscow, Russia). The names of the students have been changed.

It should be clarified that a preferred speech partner is considered to be a person with whom communication is more desirable or having more value. The communicative status of the student is determined by the number of choices made by his groupmates in his favour, when choosing a preferred speech partner in the process of experimental teaching.

Individualized Card 1 (Figure 2) has been developed for Anton, and as a teaching aid it includes the informative text (recent information about the most popular coding languages of 2015) aimed to increase his motivation by relying on his professional interests. For

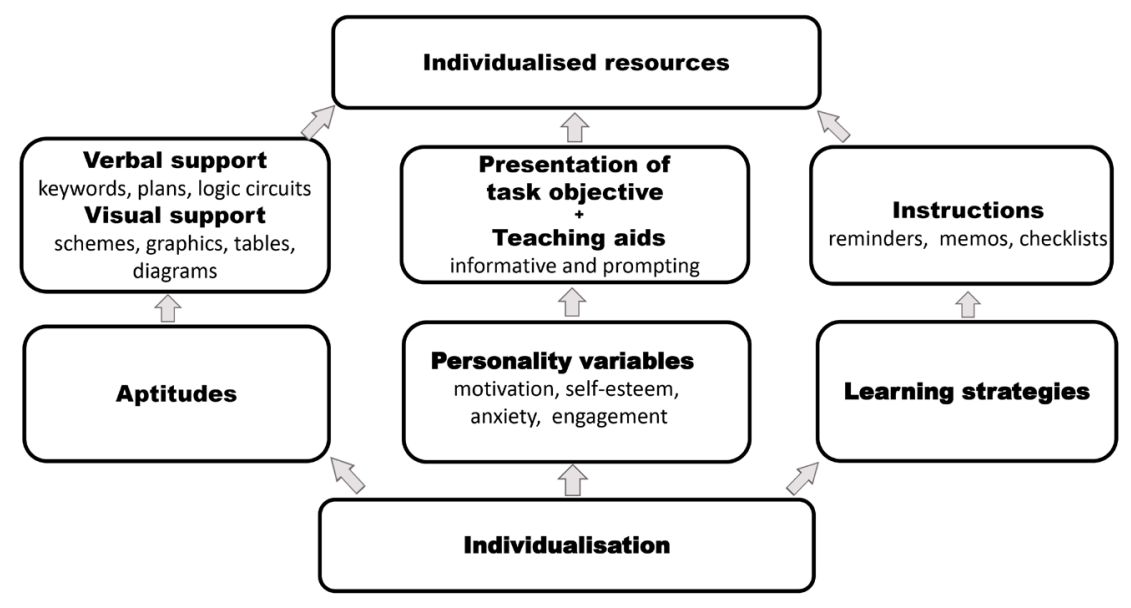

Figure 1. Individualisation as a foundation for creating individualised resources. 
support, he is given a logical plan to develop his ability to speak logically, and he was given instructions that could help him to overcome anxiety and shyness.

It should be clarified that the communicative status of the student is determined by the number of choices in his favour made by his groupmates when choosing a preferable speech partner.

Individualised Card 2 (Figure 3) has been designed for Michael. As a teaching aid, a bubble chart has been chosen (because visualisation is his preferable way of receiving information) and some facts about the most popular coding languages of 2015 aimed to maintain his motivation at a high level by relying on his professional interests. As support, he is provided with a plan to overcome contextualisation gaps, and in order to develop the ability to be a good conversation partner, he is given a memo that will remind him of some basic rules.

Individualised Card 3 (Figure 4) has been designed for Oksana. Relying on her professional interests, she is given some prompts and questions (as a teaching aid) that should become a framework for her conversation with a partner.As support, she is offered a set of words and expressions to develop an ability to speak emotionally and to keep a conversation going. As instructions, she is offered some tips about working in pairs, which may

Table 1

Anton's personal profile

\begin{tabular}{|c|c|}
\hline Individual characteristics & Tactics for individualisation \\
\hline \multicolumn{2}{|c|}{ Language aptitudes } \\
\hline $\begin{array}{l}\text { Anton has low level of aptitude for learning English. His communicative } \\
\text { abilities, the ability to guess from a context, speak logically and his } \\
\text { recall abilities all need further development. }\end{array}$ & $\begin{array}{l}\text { To give him support, the teacher should offer key words as a memory } \\
\text { developing technique, logical plans and thinking structures, and to } \\
\text { plan activities that will recycle, integrate and reinforce a certain } \\
\text { linguistic item in the context, prompting the use of the target item } \\
\text { in a communication situation. }\end{array}$ \\
\hline
\end{tabular}

\section{Learning Strategies}

His learning style is inflexible. Sometimes he has trouble with The teacher should provide him with memos about making a plan planning his oral statements, carrying on a conversation and working for his oral statements; recombination prompts that allow him with peers. to put together smaller meaningful phrases into new sentences; reminders about how to cooperate with peers effectively.

\section{Personality variables}

Anton's professional interests include programming and computing support.

He has a low communicative status (as a preferred speech partner he was chosen by one group member).

He is weakly motivated to learn a foreign language, believing that it would not be useful in the future.

He gets anxious about presenting in front of the group.

It is essential to increase his communicative status by integrating him with other members of the group, working together to solve a problem.

Motivation can be enhanced by an emphasis on professional interests. Anxiety could be reduced by using mental techniques that make him feel confident to present the learning task. Provide him with more presentation practices.

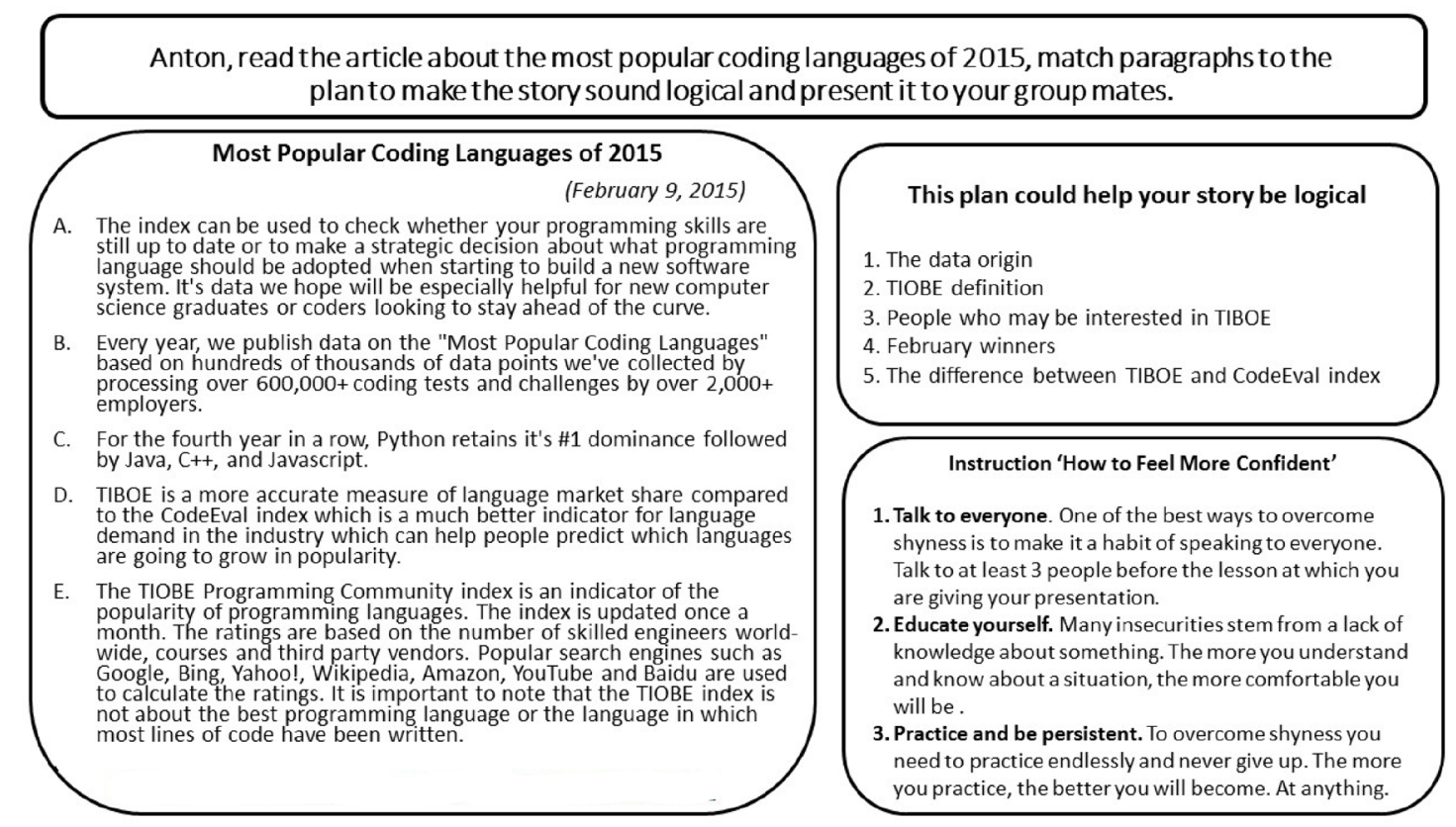

Figure 2. Individualized card 1 for Anton. Adapted from CodeEval, by CodeEval Team, 2015, Retrieved from http://blog.codeeval.com/codeevalblog/2015\#.Wgh0gmi0PIV=. In the public domain. 
help her to become a good conversational partner.

Therefore, it should be noted that individualised resources could be an effective learning tool, if they are adequately and consistently used in a series of lessons. When developing the components of individualised handouts, the teacher should take into account the students' aptitudes, learning styles and personality variables. Indeed, much depends on how much the teacher knows the student and how well the students are able to take advantage of using the individualised cards.

\section{Method}

The aim of the experimental training is to investigate that individualised resources are an appropriate tool to enhance the students' speaking abilities in terms of the purposefulness of their speech, the richness of its content and the way of logical progression of their speech. This includes the focused and consistent implementation of individualised resources, which consider students' individual personality traits and improve their quality of verbal expressions.

Table 2

Michael's personal profile

\begin{tabular}{|c|c|}
\hline Individual characteristics & Tactics for individualisation \\
\hline \multicolumn{2}{|c|}{ Language aptitudes } \\
\hline $\begin{array}{l}\text { Michael has average aptitude for foreign language learning. } \\
\text { His language analytical ability and abilities for recognition and } \\
\text { understanding of syntactical structures need further development. }\end{array}$ & $\begin{array}{l}\text { As teaching aids, he should be given semantically incomplete texts, } \\
\text { so the student can generate ideas based on incomplete content. } \\
\text { As supports, the teacher should provide him with schematic } \\
\text { grammatical rules. }\end{array}$ \\
\hline \multicolumn{2}{|c|}{ Learning Strategies } \\
\hline $\begin{array}{l}\text { Sometimes Michael has difficulties with placing a word or phrase in a } \\
\text { meaningful language sequence and relating new information to other } \\
\text { concepts in memory. It is essential to develop his skills to be a good } \\
\text { conversation partner. }\end{array}$ & $\begin{array}{l}\text { The teacher should offer instructions, which could help him to } \\
\text { overcome his difficulties with contextualisation and elaboration, } \\
\text { memos about making a plan for his oral statements and reminders } \\
\text { about how to become a good conversational partner. }\end{array}$ \\
\hline \multicolumn{2}{|c|}{ Personality variables } \\
\hline $\begin{array}{l}\text { Michael's professional interests include programming and data } \\
\text { security methods. His communicative status in a group is not very } \\
\text { high (as a preferred speech partner he was chosen by three group } \\
\text { members). His motivation for learning a foreign language is more } \\
\text { practical (instrumental motivation). }\end{array}$ & $\begin{array}{l}\text { The teacher should provide him with resources focused on his } \\
\text { professional interests that will keep his motivation at high level. It is } \\
\text { possible to increase his communicative status by offering him some } \\
\text { topics for discussion that will be of interest not only for him but for } \\
\text { other learners in the group. }\end{array}$ \\
\hline
\end{tabular}

Michael, I know that you are interested in programming languages. Read about the most popular coding languages and share the main ideas with your partner. Make use of supports and bear in mind the three stages of your talk. Ask your partner about their opinion about the problem.

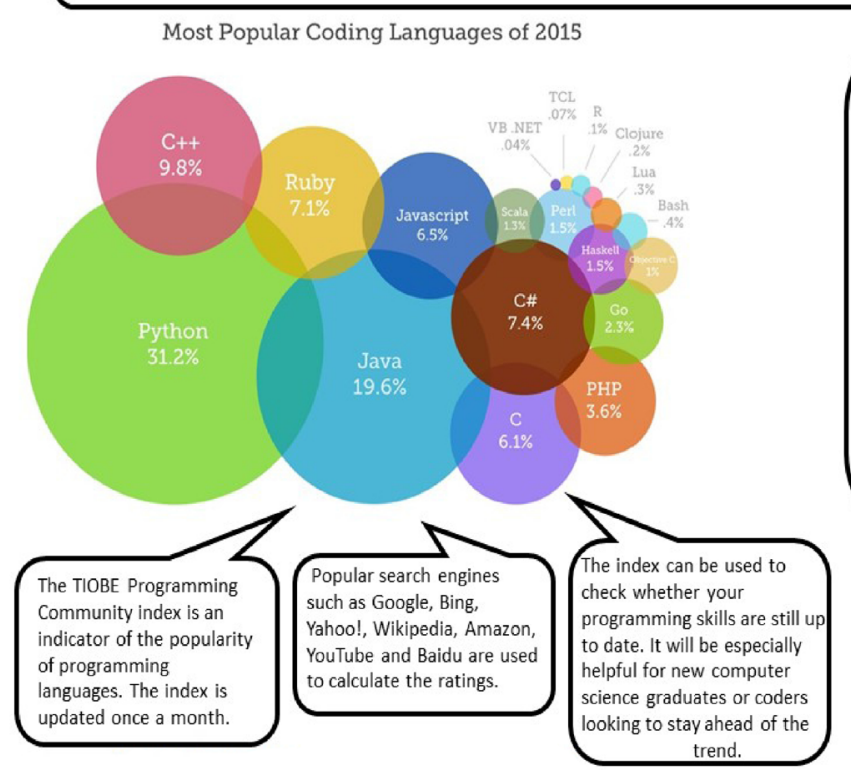

How to describe a chart
Mind the three parts:

1. Introduction.

Here you say what the diagram is about. Note the title

of it and do not forget to include the source.

The bubble chart is about... / The bubble chart

(clearly) shows...

2. Message of the diagram

It highlights .../... has the largest (number of) .../... has

the second largest (number of) .../ ... is as big as .../...

is twice as big as .../ more than ... per cent..

3. Conclusion.

Do not repeat the global message in the conclusion. So

we can say that...... I was really surprised/shocked by

the

What makes people good conversation partners?

- A desire to share some of their valuable knowledge

- Balanced listening and speaking

- Positive attitude

- Respect

Figure 3. Individualized card 2 for Michael. Adapted from CodeEval, by CodeEval Team, 2015, Retrieved from http://blog.codeeval.com/codeevalblog/2015\#.Wgh0gmi0PIV=. In the public domain. 


\section{Data Sample and Experimental Phase}

Experimental teaching using individualised resources was conducted at the Moscow Higher School of Economics while teaching English for Specific Purposes (ESP) course to 40 students from the faculty of Business Informatics. There were 20 students in the experimental group and 20 students in the control group. The experimental phase lasted for four months and in total took 72 sessions (1 session equals 45 minutes).

The topic for experimental training was the 'The role of the Internet in the modern world', which included

Table 3

Oksana's personal profile the following questions for discussion: What is the internet? What is computer-mediated communication? How do you create a website? How does your web browser find the page you want? What computer codes are used for creating a web site? What is HTML? How can you evaluate websites? How can you become a website designer?

For the experiment, a range of teaching aids were selected, such as newspaper and magazine articles, an extract or several extracts of text based on one idea, tables containing specific data, photos, illustrations, diagrams, charts and statistical data. The students were provided with individualised materials designed for

\begin{tabular}{ll}
\hline \multicolumn{1}{c}{ Individual characteristics } & \multicolumn{1}{c}{ Tactics for individualisation } \\
\hline \multicolumn{1}{c}{ Language aptitudes } \\
$\begin{array}{ll}\text { Oksana has a high aptitude for language learning. However, } \\
\text { she has to develop the ability to communicate her feelings and the teacher should offer emotional and evaluative words. } \\
\text { emotions in the foreign language. }\end{array}$ \\
$\begin{array}{l}\text { Teaching aids should include textual and visual means, which are able } \\
\text { to involve her emotionally. }\end{array}$ \\
\hline
\end{tabular}

\section{Learning Strategies}

Her social strategies like working with peers and keeping the The teacher should provide her with instructions on how to conduct a conversation going with more than one speech partners need discussion with a group of speech partners.

further development.

\section{Personality variables}

Oksana's professional interests include programming and The emphasis should be on personal and professional interests to developing new applications for smart phones. Her communicative maintain a high level of interest. In pairs, she could assist less able status in a group is high (as a preferred speech partner she was students, because teaching is a great way to learn.

chosen by seven group members). Her motivation for learning English is integrative. She is willing to put in a lot of effort to learn a foreign language.

Oksana, discuss with your partner if you should buy an Apple Watch, using questions and information given below. To make your conversation sound natural, use the following words and expressions given in the box.

\section{salary? \\ ? How long do you like being outside? \\ ? What's your favourite way of viewing information?}

What is your approximat

? What's your favourite way to tell people things?

? Should it be connected to an IPhone?

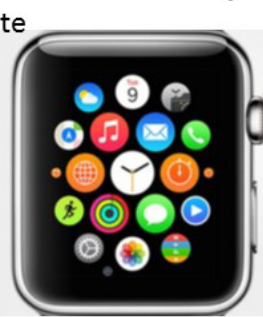

Multitude apps:

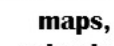

calendar,

phone calls,

passbook,

remote camera,

music,

e-mails, etc.

Types of Apple Watch:

- Apple Watch Sport

- Regular Apple Watch

- Gold Apple Watch
To make your conversation sound natural, use the following words and expression

\begin{tabular}{l|l} 
Stating an & In my opinion... The way I see it... As far as
\end{tabular} \begin{tabular}{l|l} 
opinion & I'm concerned... If you ask me...
\end{tabular}

\begin{tabular}{l|l} 
Expressing & I agree with you 100 percent. That's so true.
\end{tabular}

\begin{tabular}{l|l} 
agreement & That's for sure. You're absolutely right.
\end{tabular}

\begin{tabular}{l|l} 
Expressing & I don't think so. I'm afraid I disagree. That's
\end{tabular}

disagreement not always true.

Expressing joy, It's great! It's wonderful! Great! Beautiful! happiness $\quad$ Excellent! Terrific! I'm dying to buy...I love it!

Expressing $\quad$ How disappointing! That's too bad. That's

disappointment (just) so disappointing!

Figure 4. Individualized card 3 for Oksana. 
their learning needs and considering their aptitudes, learning strategies and personality variables.

In the experimental training, the students' answers were recorded and then analysed. In total, 570 statements were analysed according to qualities of the students' speaking ability such as purposefulness, richness of content and logical progression of speech. These traits were considered to be the most difficult for students to achieve and made the teaching process more problematic.

The experimental training was conducted in three stages:

- Preliminary stage that determined the initial level of students' speaking ability.

- Intermediate stage where the changes in students' speaking ability during the process of using the individualized resources were followed.

- Final stage, which reported the results of the experimental training.

To determine the level of students' speaking ability IELTS format Speaking test was used (see Appendix A).

\section{Data Qualification and Evaluation}

Purposefulness was measured by the relationship of the phrases 'working' for purpose goal, to the total number of phrases completed semantically. Introductory phrases that provided a transition to the main idea of their statements were taken into account as well. When determining purposefulness, every phrase was considered in the context of their statements. Thus, the total number of phrases in the students' statements was taken as $100 \%$, and the number of phrases which were considered to be 'working' towards the goal was determined as a percentage of the total number of phrases.

The richness of speech content is understood as the intensity of the oral statement's information. The richness of content index/indicator for every statement was calculated using a formula implemented by Morskaya (1972, p. 162). The main idea of a sentence which was expressed by a subject (noun) and a predicate was equated to a 'unit of information'.

Any additions and clarifications were estimated at 0.5 of a 'unit of information'. Clauses were evaluated as separate sentences. If a subject or a predicate was expressed by homogeneous parts of speech (e.g. C++, Java, HTML) all of them were each assigned a unit of 0.5 , but the first word was not. For example, in a sentence "C++, Java, HTML are high-level computer languages" the total unit of information would be 1.0. Incomplete phrases, sentences distorting the facts, repetitions and phrases that did not contribute to solving the communicative task were not taken into account.

Therefore, oral expressions which were in accordance with the task objective directly characterized the richness of the context and indirectly reflected the development of certain qualities of speaking ability such as productivity, persuasiveness and emotion.

The way of logical progression of speech was defined as the logical progression of statements in the student's discussion, where a clear introductory sentence followed by explanations and conclusions could be identified. The unit of measurement was determined as follows: for the opening phrase, the speaker received 1 point, for every phrase that logically followed on, they would receive one extra point. For example, the statement of the two phrases is worth 3 points $(1+2)$, the statement of five phrases is 15 points $(1+2+3+4+5)$. If the logical sequence is disrupted, the following phrase was estimated at 1 point, the next at 2 etc. For the concluding phrase that summarized the oral statement, the speaker was given one additional point. The use of compound sentences was marked with one point for every clause. Points were not given for repetitions and paraphrasing the same ideas. This counting technique was based on the understanding of consistency as a logical sequence of phrases, which are fluently said to reveal the main idea of the statement. Hence, the index of consistency also served as indirect evidence for qualities of speaking ability such as the richness of context and purposefulness.

Then, the students' results before, during and after the experimental teaching intervention were analysed and compared against each other using the growth index, to see whether the experimental teaching would improve their quality of speech.

\section{Results and Discussion}

The findings of this research illustrate how the intervention enhanced the students' speaking abilities in terms of their purposefulness, richness of speech content and speech progression. The data obtained during the experimental training is indicated below.

In Table 4, column ' 1 ' indicates the number of phrases in the statements, which were completed semantically. Column ' 2 ' indicates the number of phrases in the statements, which were 'working' towards the overall goal. Column ' 3 ' indicates the proportion of purposeful phrases to the total number of phrases (in \%).

In the control group, where the teacher did not use any individualized resources, it is clear that almost no changes occur, and the growth of purposefulness is $1.2 \%$ at the final stage.

The results of the intervention stage show that the students' performance improved compared to the results of the preliminary stage, which may have occurred because the task objective, support and instructions in the individualised materials were all used.

The number of phrases that invited discussion with 
an interlocutor and therefore facilitated the students' speaking activity markedly increased: I think that, I'm not sure that, as far as I know, there's no denying that, no way!

The 10\% increase in the final stage of the experimental group demonstrates that students are able to build purposeful statements when they communicate.

When analysing the data from Table 5 , we can see that the control group's growth index is only $6.5 \%$, which is markedly lower than that for the experimental group, which used the intervention.

As for the experimental group, the variety of material and operating tools, which were offered to the students, allowed them to make significant progress in learning how to vary the richness of their speech. The proportion of growth for the experimental group was $73 \%$. This could be because teaching aids for experimental training are highly informative and aimed at their professional interests.

The review of the students' answers in the experimental group revealed that their speech patterns in the final stage, compared to the preliminary stage, were characterised by a higher degree of argumentation and relevance.

Thus, the data show the effectiveness of individualised resources as a way of shaping student's vocabulary.

Table 6 indicates that the average growth rate of the learning the way of logical progression of speech in control group is $51 \%$. It is assumed that the impetus for this could be the systematic use of the supports and instructions, which aimed to develop the students' ability to express themselves more logically.

In the control group, there is a minor increase in the development of speech progress, and the index of growth is $5 \%$. This can be explained by the fact that the teacher from time to time assigned tasks, which aimed to develop the students' logical ability although this was insufficient.

Over the period of experimental training, the students learned to expand their ideas gradually, to avoid repetition. Moreover, the number of clauses and summarising phrases increased as did the overall number of phrases in the statement.

Here is an example of the student's ability to speak at the final stage of the experimental teaching (see Appendix B).

One of the best programming languages I am going to talk to you about is Java. I am not saying this because I can code Java, but Java has proved it in last 20 years.

First of all, Java is everywhere, it's on desktop, it's on mobile, it's on card, I mean almost everywhere. Java has Rich API. Java API, well, API is an application programming interface, is used for networking, database connections, inputs/outputs and utilities, everything.

Furthermore, because Java is open source, it is used in more places than some of its competitors. One job placement company did a marketplace analysis and found that $20 \%$ of the openings called for Java skills, either alone or in addition to other programming languages.

You can get a lot of Jobs opportunity by learning Java programming language. You can develop core Java based server side application, enterprise applications, and you can even develop Android based mobile applications.

If you decide to learn Java programming, I personally suggest picking a book, because they are almost always written well for beginners. I personally recommend 'Head First Java' to beginners, that's great book to start, if you don't know much about Java. Online tutorials will also can help you to learn Java.

Table 4

Purposefulness measured for the experimental and control group

\begin{tabular}{|c|c|c|c|c|c|c|c|c|c|c|}
\hline \multirow{2}{*}{$\begin{array}{l}\text { Group } \\
\text { category }\end{array}$} & \multicolumn{3}{|c|}{ Preliminary stage } & \multicolumn{3}{|c|}{ Intervention stage } & \multicolumn{3}{|r|}{ Final stage } & \multirow{2}{*}{$\begin{array}{c}\text { Growth } \\
\text { index (\%) }\end{array}$} \\
\hline & 1 & 2 & $\begin{array}{l}3 \text { Proportion of pur- } \\
\text { poseful phrases (\%) }\end{array}$ & 1 & 2 & $\begin{array}{l}3 \text { Proportion of pur- } \\
\text { poseful phrases (\%) }\end{array}$ & 1 & 2 & $\begin{array}{l}3 \text { Proportion of pur- } \\
\text { poseful phrases (\%) }\end{array}$ & \\
\hline Experimental & 8.4 & 6.1 & $70.8 \%$ & 10.5 & 7.9 & $75.0 \%$ & 12.6 & 10.3 & $81.3 \%$ & $+10.5 \%$ \\
\hline Control & 8.2 & 5.7 & $69.5 \%$ & 8.5 & 5.9 & $69.4 \%$ & 8.8 & 6.2 & $70.7 \%$ & $+1.2 \%$ \\
\hline
\end{tabular}

Table 5

The richness of speech measured for the experimental and control group

\begin{tabular}{|c|c|c|c|c|}
\hline Group category & Preliminary stage & Intervention stage & Final stage & Growth index (\%) \\
\hline Experimental & 7.8 & 10 & 13.5 & $+73.0 \%$ \\
\hline Control & 7.7 & 7.9 & 8.2 & $+6.5 \%$ \\
\hline
\end{tabular}

Table 6

Logical progression of speech measured for the experimental and control group

\begin{tabular}{|c|c|c|c|c|}
\hline Group category & Preliminary stage & Intervention stage & Final stage & Growth index (\%) \\
\hline Experimental & 17 & 21.6 & 25 & $+51 \%$ \\
\hline Control & 17,3 & 17,7 & 18,2 & $+5.0 \%$ \\
\hline
\end{tabular}


I meant to say earlier that one of the reasons for learning Java it is easy to learn. Java has English like phrase structure, you know, arrangement of words, with minimum angle brackets, which makes it easy to read Java program. It does not require any prior programming experience to learn Java coding. Learning Java can be really easy if you already know a programming language.

Finally, if you are a programmer, you should always keep learning. This is because there is no place for outdated professional skills in programming. It is very important to keep up with the latest trends in order to be competitive. The best way is to put new knowledge into practice. I recommend reading Java and Technology Sites and Blogs from experts.

The student's speech was clearly outlined and structured and this made it easy to follow. The student introduced his topic (One of the best programming languages I am going to talk to you about is Java), and covered all the points in his assignment, wherein each point was clearly introduced in a logical succession (First of all..., Furthermore..., If you decide to learn Java programming..., Finally...). Using repair strategies allowed him to include an idea, which had not been mentioned in the main structure of the talk (I meant to say earlier...) and to repeat a phrase to avoid hesitation (Java is everywhere... ...I mean almost everywhere). He paraphrased when he could not remember a word 'syntax' (phrase structure, you know, arrangement of words...) and clarified some technical terms (API is an application programming interface ...). The student demonstrated the ability to speak at length and keep going. Since this topic was discussed previously, he had plenty of ideas to express. As a result, his talk could be considered as purposeful, logical and rich in content.

In Table 7, an overview of the indicators in the experimental group as compared to the control group can be seen. Overall, in the control group, there is no significant growth of any indicator. The exceptions are the richness of speech, where we can see a 7\% increase due to the quality of teaching aids which were specially prepared for the experimental training.

The ratio of the average growth of indicators in the control and the experimental groups for purposefulness is 8.75 , for the richness of speech it is 12 and in for speech progression it is 10.3 .

After comparing the data from the experimental and control group, it can be concluded that if teachers do not search for adequate ways to work on the development of their students' speaking skills, then they cannot expect high indicators of their oral speech performance.

The results of the research showed that after using individualised resources in the experimental group, the quality of verbal expressions significantly increased and the students' speaking abilities, particularly in terms of the purposefulness of their speech, the richness of its content and their logical speech progression also enhanced.
The final stage of the experiment showed that the students' performance improved compared to the results of the preliminary stage, which may have occurred due to the use of the task objective, supports and instructions in the individualised materials. Moreover, the variety of material and prompts, which were offered to the students allowed them to make significant progress in learning.

In the process of intervention, the students demonstrated an ability to relate to the facts and events presented using their own personal experience, interests and abilities. Structurally, the texts offer a model for future statements that the students will make. The task objective presentation aimed to motivate students to produce their own speeches. The verbal and visual supports help students to develop their recall abilities and to organise their speech more productively, using a variety of words and expressions. The instructions help them to perform their tasks more effectively and logically and develop the students' learning strategies.

There are two factors, which mean that additional training tools are required; first, a focus on the fact that the student body is comprised of diverse individuals, and second, the demand for personalised curricular materials to satisfy the needs of each student (Bray \& McClashey, 2015).

Within the context of this study, a solution has been found using the individualised handouts as an extra training tool for the development of students' speaking skills. However, it can only be an effective tool if it meets the following six criteria:

1. Individualisation: the idea of individualisation must provide the theoretical grounding for the individualised resources, where the content and instructional technology of learning are based upon the aptitudes, learning strategies and personality variables of each student.

2. Resources: each component of individualisation should be manifested in individualised resources (i.e. aptitudes should be represented by verbal and visual supports, learning strategies should be indicated by instructions and personality variables by the presentation of task objective and teaching materials).

3. Process: the tactics of individualisation described in the student's personal profile should

Table 7

Summary table of indicators of growth

\begin{tabular}{lccc}
\hline $\begin{array}{c}\text { Group } \\
\text { category }\end{array}$ & $\begin{array}{c}\text { Growth in the } \\
\text { purposefulness } \\
\text { indicator, } \%\end{array}$ & $\begin{array}{c}\text { Growth in } \\
\text { the richness } \\
\text { of speech indi- } \\
\text { cator, \% }\end{array}$ & $\begin{array}{c}\text { Growth in } \\
\text { the speech } \\
\text { progression } \\
\text { index, } \%\end{array}$ \\
\hline Experimental & $+10.5 \%$ & $+78.3 \%$ & $+51.3 \%$ \\
\hline Control & $+1.2 \%$ & $+6.5 \%$ & $+5.0 \%$ \\
\hline \multicolumn{5}{c}{ The ratio of the average growth of indicators } \\
\hline \multicolumn{4}{c}{12} \\
\hline
\end{tabular}


determine the content of these components.

4. Components: the structural components of the individualised resources should be the presentation of the task objective, material teaching aids, instructions and supports. Each of these components to a varying degree should contribute to the overall goal of teaching oral communication in a foreign language.

5. Consistency: in order to be an effective learning tool, individualised resources should be adequately and consistently used in a series of lessons, rather than in isolated sessions.

6. Accessibility: The students must be taught to make use of the individualised resources, so that they achieve the maximum potential from them. Following these criteria, the teachers create individualised resources, which could be an effective learning tool, if they are adequately and consistently used in a series of lessons.

\section{Conclusion}

This paper provided some suggestions on how the students' speaking abilities can be improved through designing and using individualised resources, which help the students to be actively involved in the learning process, contribute to their productivity of learning and compensate for missing abilities when learning English as a foreign language. Research findings illustrated how the approach enhanced the students' speaking abilities in terms of purposefulness, richness of speech content and logical progression of speech. The results presented in the article indicated that this type of training may be sufficient to shape speaking skills when teaching English for Specific Purposes to the students from the faculty of Business Informatics at the Moscow Higher School of Economics.

Although the research has reached its aims, there are some potential limitations that may interfere with its implementation in the everyday teaching practice. First, it is time consuming to create a personal profile and individualised cards for every student. Each student is different and the teacher must be aware of their individual differences. However, in order to reduce the amount of work that the teacher will have to do, a personal profile, which includes language aptitudes, learning strategies, personality variables, and the ways they prefer to learn could be filled out by the students at home, with guidance from their teacher and possibly their parents. This would be a very powerful tool because it helps the students to evaluate themselves and how they learn. This will save much more time for the teacher when making the individualised cards, and be very helpful for the students' further development. Another way to overcome this limitation could be to build a team of co-teachers to research individualised learning and as a team work on collecting a database of teaching aids, and share them to create tasks, which match the individual students' needs.

The results presented here have highlighted a number of topics on which further research would be beneficial. First, future studies should address the different ways of modifying individualised resources, particularly for pair and group work, and for different types of verbal expression (e.g. monologues, dialogue, and group discussion) as well as the content of individualised handouts. A more detailed elaboration of all the structural components of individualised resources could be a good contribution to this research. Second, further investigation with a larger sample size and perhaps with a different study body such as high school students or working professionals, would be interesting to consider. This would lead to a wider range of data and allow the development of new types of individualised resources for different age groups and different needs. This would offer a better impression of the overall performance of the individualised resources, and allow a comparison between the results of different groups of students.

In Russia, until the 1990s, the predominant instructional materials were printed textbooks and worksheets, which were fixed and inflexible. Since there were no obvious alternatives, the students became accustomed to only one method of learning. This has started to change with the advent of computer technology and influences from other countries on the educational system. However, creativity is still lacking in most Russian schools across the country. Therefore, these individualised resources offer a creative alternative to the existing dry methods of teaching. They are based on the diversity of all students and can be adapted to a variety of their specific needs and the ways in which they learn best.

\section{References}

Biggs, J. B. (1992). Study process questionnaire. Why and how do Hong Kong students learn? Using the learning and study process questionnaires (Education Paper No.14). Faculty of Education, University of Hong Kong, Hong Kong.

Bray, B., \& McClaskey, K. (2015). Make learning personal. The what, who, wow, where and why. Thousand Oaks, CA: SAGE Publications.

Brodkey, D., \& Shore, H. (1976). Student personality and success in an English language program. Language Learning, 26(1), 153-162.

Brown, H. D. (1994). Principles of language learning and teaching (3rd ed.). Englewood Cliffs, NJ: PrenticeHall. 
Carroll, J. (1981). Twenty-five years of research on foreign language aptitude. In K. C. Diller (Ed.), Individual differences and universals in language learning aptitude (p. 83-118). Rowley, MA: Newbury House.

Coopersmith, S. (1967). The antecedents of self-esteem. San Francisco, CA: W. H. Freeman \& Company.

Crookes, G., \& Schmidt, R. W. (1991). Motivation: Reopening the research agenda. Language Learning, 41(4), 469-512.

Diamond, R. M. (1975). Instructional development for individualized learning in higher education. Englewood Cliffs, NJ: Educational Technology Pub.

Dörnyei, Z. (2005). The psychology of the language learner: Individual differences in second language acquisition. Mahwah, NJ: L. Erlbaum

Ehrman, M. E. (1996). Understanding second language learning diffiulties. Thousand Oaks, CA: Sage.

Gardner, R. (1985). Social psychology and second language learning: The role of attitude and motivation. London, UK: Edward Arnold.

Gardner, R., \& MacIntyre, P. (1993). A student's contributions to second-language learning. Part II: Affective variables. Language Teaching, 26, 1-11. doi:10.1017/S0261444800000045

Heyde,A. (1979). The relationship between self-esteem and the oral production of a second language (Unpublished doctoral dissertation). University of Michigan, Ann Arbor, MI.

Horwitz, E., Horwitz, M., \& Cope, J. (1986). Foreign language classroom anxiety. The Modern Language Journal, 70, 125-132.

Kormos, J., \& Dörnyei, Z. (2000). The role of individual and social variables in oral task performance. Language Teaching Research, 4, 275-300.

Kuzovlev, V. P. (1997). Osnovy professional'noj kul'tury [Fundamentals of the teacher's professional culture]. Lipetsk, Russia: LGPI.

Morskaya, V. A. (1972). Opytnaja proverka effektivnosti vlijanija otdel'nyh stimulov na nepodgotovlennoe vyskazyvanie na starshih kursah jazykovogo vuza [Experimental verification of the effectiveness of some incentives on unprepared oral statement at the language university]. In The methodology of teaching foreign languages in the university (Vol. 2, pp. 111117). Moscow, USSR: MGPIIJa im. M. Toreza.

O’Malley, J. M., \& Chamot, A. U. (1990). Learning strategies in second language acquisition. Cambridge,
UK: Cambridge University Press.

O’Malley, J.M., \& Chamot, A.U. (1993). Learner characteristics in second-language acquisition. In A. Omaggio Hadley (Ed.), Research in language learning: Principles, processes, and prospects (pp. 96-123). Lincolnwood, IL: National Textbook.

Ochsenfahrt, K. (2012). Motivation as a factor in second language acquisition. Munich, Germany: GRIN Publishing.

Oxford, R. (2001). Integrated skills in the ESL/EFL classroom. Retrieved from http://www.ericdigests. org/2002-2/esl.htm

Oxford, R. (1990). Language learning strategies: What every teacher should know. Boston, MA: Heinle \& Heinle.

Passov, E. I., \& Kuzovleva, N.E. (2010). Urok inostrannogo jazyka [A lesson of a foreign language]. Moscow, Russia: Glossa-Press.

Reid, J. (1995). Learning styles in the ESL/EFL classroom. Boston, MA: Heinle \& Heinle.

Rogova, G. V., Rabinovich, F. M., \& Sakharova, I.E. (2004). Metodika obuchenija inostrannym jazykam v srednej shkole [Methods of teaching foreign languages in secondary school]. Moscow, Russia: Prosveshchenie.

Skehan, P. (1998). A cognitive approach to language learning. Oxford, UK: Oxford University Press.

Sparks, R. L., \& Ganschow, L. (1991). Foreign language learning differences: Affective or native language aptitude differences? The Modern Language Journal, 75, 3-16. doi:10.1111/j.1540-4781.1991.tb01076.x

Sternberg, R., \& Grigorenko, E. (2002). The theory of successful intelligence as a basis for gifted Education. Gifted Child Quarterly, 46(4), 265-277.

Stognieva, O. N. (2003). Ispol'zovanie individualizirovannogo razdatochnogo materiala pri obuchenii rechevomu vyskazyvaniju [Developing speaking skills while teaching English as a foreign language through the implementation of individualised resources] (Unpublished $\mathrm{PhD}$ thesis). Moscow Pedagogical State University, Moscow, Russia.

Ushioda, E. (2009). Self-esteem and foreign language learning. Newcastle, UK: Cambridge Scholars Publishing.

Zimnaya, I. A. (1985). Psihologicheskie aspekty obuchenija govoreniju na inostrannom jazyke [Psychological aspects of teaching speaking a foreign language]. Moscow, Soviet Union: Prosveshchenie. 


\section{Appendix A}

\section{Speaking Part 2 task. Variant 1}

Describe a website that you like using. You should say:

- what this website is

- how people use it

- who uses it and explain why you often browse this website

\section{Appendix B}

\section{Speaking Part 2 task. Variant 2}

Describe the best programming language from your point of view. You should say

- what the language is

- what it is used for

- how you can learn it and explain why you should learn it 